\title{
ENGINE OIL ANALYSIS - EFFECTIVE INSTRUMENT TO EVALUATE RELIABILITY OF TRACTOR ENGINES
}

\author{
Marie Sejkorova, Ivana Hurtova \\ University of Pardubice, Czech Republic \\ marie.sejkorova@upce.cz, ivana.hurtova@upce.cz
}

\begin{abstract}
The economy of operation of agricultural machinery depends on its technical condition. In the case of damage to machinery that is associated with leakage of lubricants, there is contamination of the soil, water and also contamination of the food chain. The engine oil analysis is one of the effective methods to determine the optimum exchange intervals of oil, to monitor the technical conditions of machinery individual components and to predict equipment failure. The paper presents and compares the results of the experimental evaluation of degradation after the engine oil has exceeded the exchange interval recommended by the manufacturer for the specially-developed lubricant TORQ-GARD used in tractors by the manufacturer John Deere. The lubricant degradation was evaluated by FTIR spectrometry and viscosity assay. The engine wear process was evaluated by non-disassembly diagnosis based on the analysis of the wear particles in the lubricant. Although John Deere tractors were exposed to high loads during many agricultural works, no negative changes of the parameters of the used lubricant or increased wear of the engine occurred. The combination of FTIR spectrometry, monitoring of viscosity and ferrography proved that the specially developed TORQ-GARD oil satisfies the highperformance demands on the engine needs, as declared by its producer; therefore, it is suitable for the demanding operational conditions in agriculture.
\end{abstract}

Keywords: oil analysis, lubricant quality, engine oil, tractor, reliability.

\section{Introduction}

Powerful and reliable machinery is one of the key prerequisites for ensuring and implementing agricultural production plans. Reliability and durability of agricultural machinery engines depend not only on the operating conditions, but also on the actual properties of oil refills. Fluid's purity in agricultural machinery is one of the most important features in the entire process [1;2].

While operating in the lubrication system of the engine, lubrication oils are exposed to high temperatures, high pressures and undesirable contaminations, such as combustion products, water and cooling liquid, unburned fuel, outer contaminants, and abrasive metals. In the real operation of agricultural machines, other factors affect the life of the engine oil too, including:

- engine design,

- load level of the motor (velocity, torque demand),

- content of sulphur in the fuel,

- engine power/volume of cylinders.

These factors have impact on the endurance of the lubricants as well as the wear of the engine parts.

Regardless of the type of oil used in the agricultural machinery, degradation and/or contamination under complicated working conditions cannot be avoided [3-5]. There are many causes that can lead to degradation of the lube oil. The most common are oxidation, thermal breakdown of the lube oil, additive depletion and contamination [6;7]. Hydraulic and transmission fluid requires monitoring quality parameters (regarding any concentration of metallic elements and any concentration of chemical elements representing the additives). Kosiba at al. [8] examined lifetime test of the hydraulic and transmission oil, Shell Spirax S4 ATF (Universal Tractor Transmission Oil (UTTO)). This fluid was used in the hydraulic and transmission circuit of John Deere 5720 tractor.

Macian et al. [9] stated that oil analysis is an advanced technique and was widely used around the world as a suitable method of reducing maintenance costs, improving reliability and productivity. For observing thermal and oxidation degradation and leakage of contaminants into the lubricating oil the FTIR spectrometry is used [10;11]. A lubricant's viscosity is its most important property [12;13]. Viscosity has direct bearing on the wear protection, and the engine is designed to operate at its best when using motor oil of specific viscosity. The intense pressure the oil bears when it is squeezed between moving parts, like at the piston ring/cylinder wall interface, can tear apart, or shear its molecular structure, leading to viscosity loss. Fuel can wash past the piston rings and contaminate 
motor oil, causing it to lose viscosity. Excessive fuel dilution leads to sludge and varnish, requiring lubricant to be changed more often.

A sample of oil not only bears information about its physical and chemical status, but also provides important information about the technical status of the lubricating system (engine). The information is provided primarily by the quantification of the scattered abraded metal particles (worn particles) found in the lubricant, based on which it is possible to indirectly track mechanical changes in the lubricating system. Ferrography is a method that appears to be appropriate for qualitative description of morphology and size characteristics. Based on the results of ferrography [14], it is possible to assess the reasons and process of wear in an evaluated system. The device that works based on the principle of counting the particles is LaserNet Fines (LNF). With this device information on the number, size and morphological structure of wear particles can be obtained in a very short time $[15 ; 16]$. Atomic emission spectrometry is used to determine the degree of wear of friction pairs, the concentration of additives in a lubricant and the concentration of contaminants [1719].

The paper presents the results of the analysis of degradation of TORQ-GARD lubricating oils operated in JOHN DEERE tractors and the influence of the current quality of the oil filling on the characteristics of the engine wear.

\section{Materials and methods}

Table 1 shows the technical specifications related to both the tractors and the operated engine oil fillings.

Table 1

Technical specifications of tractors and operated oil fills

\begin{tabular}{|c|c|c|c|c|c|}
\hline $\begin{array}{l}\text { Marking of tractors } \\
\text { JOHN DEERE }\end{array}$ & 6230 & 6920 & 7810 & 8100 & 8220 \\
\hline Engine type & \multicolumn{5}{|c|}{ turbo diesel } \\
\hline Number of cylinders & 4 & 6 & 4 & 6 & 6 \\
\hline Cooling & \multicolumn{5}{|c|}{ liquid } \\
\hline Production year & 2004 & 2005 & 1999 & 1998 & 2004 \\
\hline $\begin{array}{l}\text { Recommended oil change } \\
\text { interval, Eh }\end{array}$ & 250 & 250 & 250 & 250 & 250 \\
\hline $\begin{array}{c}\text { Operation of engine oil } \\
\text { change, Eh }\end{array}$ & 255 & 257 & 255 & 256 & 249 \\
\hline Overall operation. Eh & 2750 & 1750 & 5855 & 9056 & 750 \\
\hline Marking of engine oil & \multicolumn{5}{|c|}{ TORQ-GARD, SAE 15W-40, API Cl - 4 Plus } \\
\hline
\end{tabular}

Comment: unit Eh - engine hours

FTIR spectrometry was used for observing the degradation of the lubricant, its contamination and additives depletion. Kinematic viscosity was observed using the Stabinger viscometer. Ferrography analysis was used to analyse the wear particles released into the engine oil. We can indirectly observe mechanical changes in the system in which the lubricant is applied by analysing the particle wear.

\section{FTIR spectrometry}

Chemical degradation of the motor oil, its contamination, penetration of contaminants and loss of additives were determined on qualitative basis through comparison of IR spectra of the new and worn oils. For this purposes, we used the spectrometer VECTOR 22 (Bruker), a spectrometer with ATR attachment (crystal ZnSe) using a fully reduced reflectance technique. The spectra of the measured engine oil samples ranged from 4000 to $600 \mathrm{~cm}^{-1}$, resolution $4 \mathrm{~cm}^{-1}$, the number of spectrum accumulations 32 .

\section{Kinematic viscosity}

Experiments were carried out using the SVM 3000 Stabinger viscometer by Anton-Paar (Graz, Austria). It is a modified rotational viscometer that can be used for measurements of viscosity and density of the engine oils and liquid fuels in accordance with ASTM D7042 standards. Based 
on the measured values of the dynamic viscosity and density, the device automatically computes the kinematic viscosity at $100{ }^{\circ} \mathrm{C}$.

\section{Ferrography}

The oil fills were analysed by the REO1 (Reo Trade Ostrava, Czech Republic) ferrograph, and the obtained ferrograms were examined by using the bichromatic binocular microscope H6000 (Intraco Micro Tachlovice, Czech Republic) and the digital camera Nikon Coolpix 4500 connected to the THOMSON television. For dimensional evaluation of the observed particles we used a stage micrometer with one division $=10 \mu \mathrm{m}$ (L.E.T. Optomechanika Prague Ltd., Czech Republic).

In order to get a representative sample of the lubricating oil fill, the collected samples were heated to $65^{\circ} \mathrm{C}$ and homogenized for five minutes by shaking before the ferrographic analysis was performed.

\section{Results and discussion}

JOHN DEERE tractors are used in a wide range of agricultural work. This imposes considerable demands on the performance and quality parameters of the engines. Although the age of the individual tractors is different, the FTIR spectra of the worn oils taken from these tractors are very similar (Fig. 1). The manufacturer recommends to exchange the oil every $250 \mathrm{Eh}$. According to Bekana at el. [20] the practice of changing the engine oil at 250 Eh is not justified correctly.

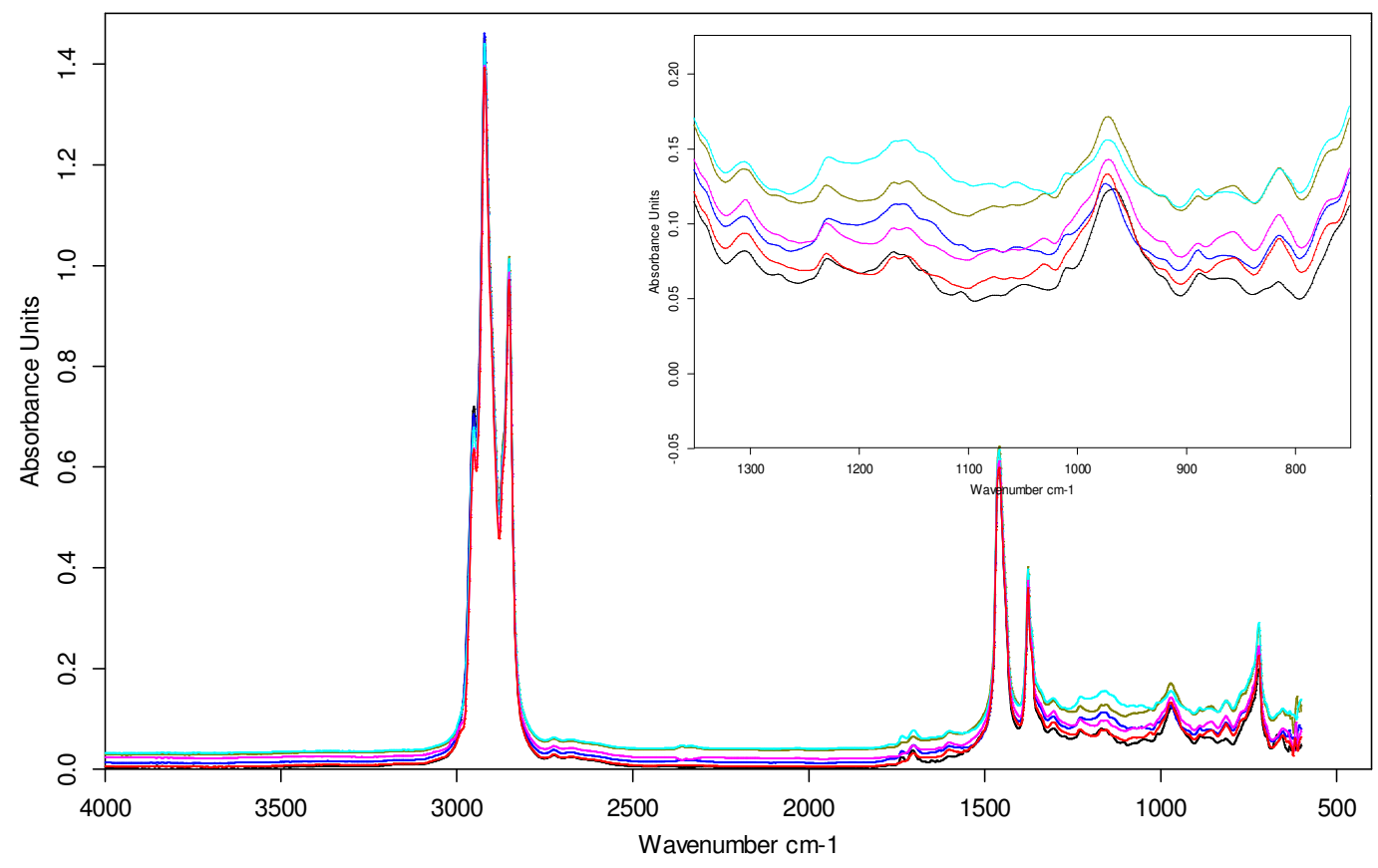

- new engine oil TORQ-GARD

- used engine oil from tractor 6320 (extended change interval by $5 \mathrm{Eh}$ )

- used engine oil from tractor 6920 (extended change interval by 7 Eh)

- used engine oil from tractor 8100 (extended change interval by $6 \mathrm{Eh}$ )

- used engine oil from tractor 8220 (shortened change interval by $1 \mathrm{Eh}$ ) used engine oil from tractor 7810 (extended change interval by $5 \mathrm{Eh}$ )

\section{Fig. 1. Spectrum of new engine oil and used oils with shortened and extended change interval}

Wear of the oil filling occurs in all tractors without significant changes, the slight decrease in absorbance in the area of about $1050-950 \mathrm{~cm}^{-1}$ is related to the gradual depletion of the lubricating and antioxidant additive ZnDDP (Zinc Dialkyldithiophosphate). The reduction in the concentration of this additive is the most remarkable in case of the tractor 7810, where the exchange interval was extended by $5 \mathrm{Eh}$. The $1180 \mathrm{~cm}^{-1}$ absorption zone signals a slight increase in the content of sulfur compounds produced by incomplete fuel combustion (most noticeable with the tractors 7810 and 
8220). No engine oil was found to have intensive zones in the area of about $1550-1750 \mathrm{~cm}^{-1}$ that would relate to increased thermal-oxidative stress of the oil (see Fig. 1). By comparing the spectra of the new lubricant and the worn lubricants, zones in the range of $1580-1650 \mathrm{~cm}^{-1}$ belonging to organic nitrates (ie. products resulting from the reaction of the oil with nitrogen oxides from combustion gases) were not recorded. Nitrogen oxides would only get into the oil filling in case of the piston ring leaks. In the wavelength area of about $800 \mathrm{~cm}^{-1}$, a zone characterizing the diesel is visible. The fuel, along with the combustion products, gets from the cylinder area around the piston rings to the crankcase. Diesel fuel in the crankcase reduces viscosity leading to piston seizure, decreased bearing life, high oil consumption, and piston deposits. Deposits on pistons cause the rings to stick, resulting in the accelerated engine wear and increased oil contamination. Raw fuel may run down the cylinder walls, past the rings. This washes away the lubricating oil and increases the engine wear. Since the diesel distillation curve starts at around $160{ }^{\circ} \mathrm{C}$ and the oil operating temperature is usually around $100{ }^{\circ} \mathrm{C}$, the diesel cannot evaporate from the oil. The permissible fuel volume in the oil filling is $4 \%$. The evaluated oil samples contained neither water (wide zone $3600 \mathrm{~cm}^{-1}$ to $3300 \mathrm{~cm}^{-1}$ ), nor glycol (zones $1040 \mathrm{~cm}^{-1}, 1080 \mathrm{~cm}^{-1}$ ). If there is coolant in the oil, it means that the gasket under the engine head has broken or the rubber bands on the piston inserts were sealed or agglomerated.

The value of the viscosity of the engine oils is influenced by contradictory aspects. Thermooxidation products and soot increase the viscosity of the oil. Conversely, the reason for the decrease in the viscosity can most often be the fuel penetration into the lubricating oil or shear instability of the viscosity modifiers. The kinematic viscosity at $100{ }^{\circ} \mathrm{C}$ for the new engine oil was measured with the Stabinger viscometer $\left(\gamma=95.35 \mathrm{~mm}^{2} \mathrm{~s}^{-1}\right)$. As a critical value, Urzędowska [21] publishes the viscosity change of $\pm 15 \%$ relative to the value of the new oil. At $100{ }^{\circ} \mathrm{C}$ the viscosity values of the oils used ranged from 85.08 to $99.51 \mathrm{~mm}^{2} \mathrm{~s}^{-1}$, i.e. they did not exceed the critical limit.

Ferrographic analysis was carried out on the tractor oil fillings diagnosis, which provides information about the lubrication and friction ratios in the engine. According to the microscopic analysis of the wear particles, it can be stated that the course of motor wear is defect-free, only fine adhesive particles in the form of chains occurred in the ferrograms, without occurrence of the critical emergency particles (Figs. 2-5). In ferrograms there were no particles of abrasive wear bigger than $>15 \mu \mathrm{m}$. There were only very small particles of common adhesive wear arranged into strings. These strings follow the direction of force lines of the magnets placed under the foil.

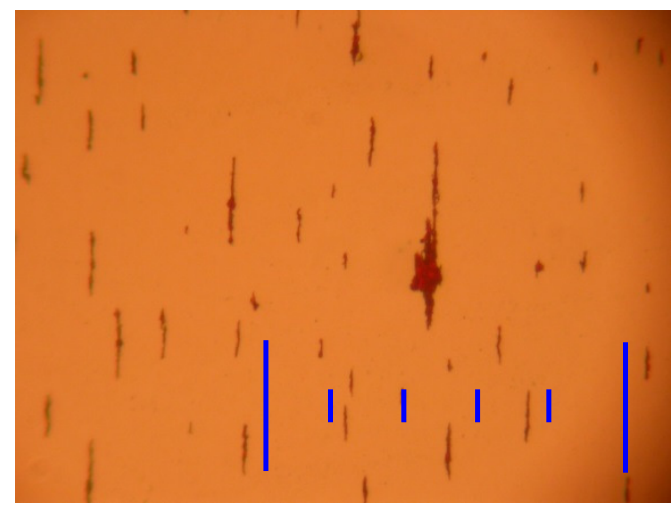

Fig. 2. Oil ferrogram of 7810 tractor - wear particle chains - zoomed 400x $(1$ segment $=10 \mu \mathrm{m})$

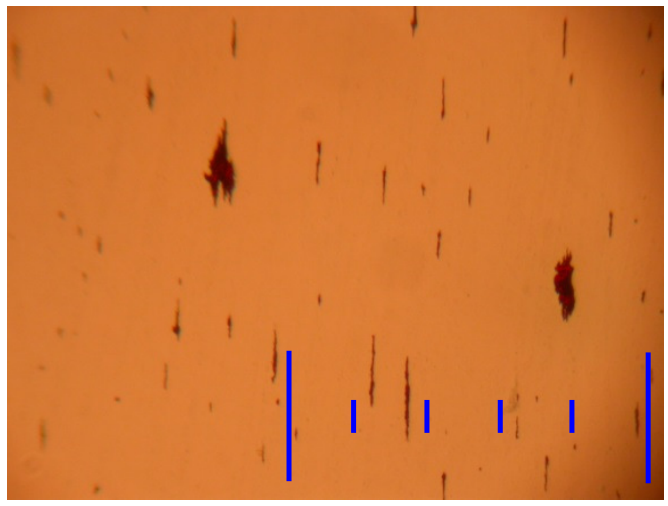

Fig. 3. Oil ferrogram of 8220 tractor - wear particle chains - zoomed $400 \times$ $(1$ segment $=10 \mu \mathrm{m})$

Although the tractors are subjected to high loads during the agricultural work, there has been no negative change in the parameters of the oil fill used as well as no increased engine wear. Thus, instrumental methods of tribotechnical diagnostics proved that the specially developed TORQ-GARD engine oil meets the high performance and engine requirements of its manufacturer and the difficult operating conditions in agriculture. Also, Bekana et al. [20] tested the engine oils collected after 250 Eh from relatively new tractors. They came to the conclusion that the recommended change interval after $250 \mathrm{Eh}$ is not adequate for a good condition of the evaluated used engine oils. 


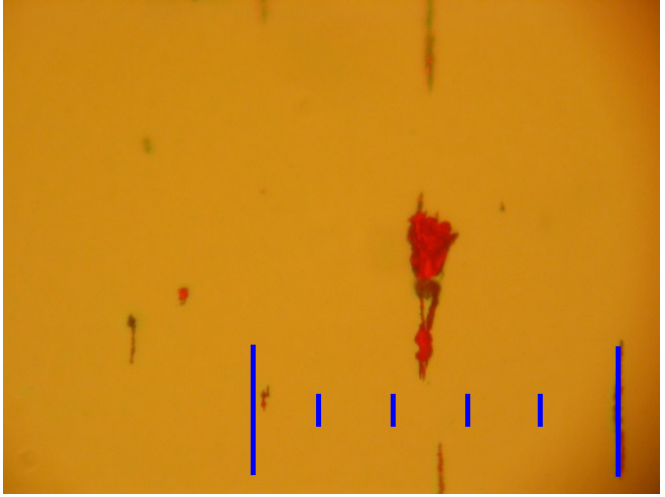

Fig. 4. Engine oil ferrogram of 8100 tractor normal adhesive wear with unique occurrence of particles of about $10 \mu \mathrm{m}-$ zoomed 250× $(1$ segment $=10 \mu \mathrm{m})$

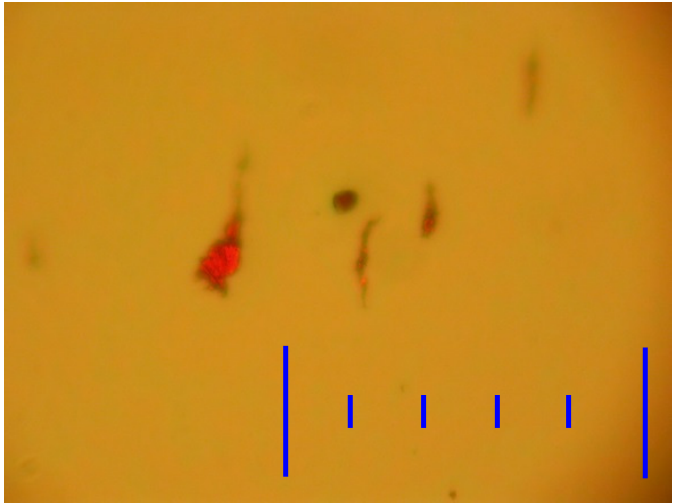

Fig. 5. Engine oil ferrogram of 6920 tractor - normal adhesive wear - zoomed $100 \times(1$ segment $=10 \mu \mathrm{m})$

The FTIR spectrometry and analytical ferrography methods were also used by Sejkorová [22] for evaluation of the operated motor oils M7ADS III and M6ADS, collected from the older types of ZETOR tractors. Change intervals of oils were extended for most tested engine oil fills. In this case, the analysis results showed that it is not advisable to extend the change interval of motor oil. Also, Plaščak et al. [23] accentuate and review the position and significance of ferrography for early prediction of machinery wear.

\section{Conclusions}

The paper presents the results of the analysis of TORQ-GARD, SAE 15W-40 oils used in John Deere tractors. On the basis of the results the following can be stated:

1. Although the John Deere tractors had been exposed to high load of agricultural work, no negative change of the engine oil parameters or increased wear of the engine occurred or engine failure,

2. Results of the FTIR spectrometry, analytical ferrography and monitoring of the viscosity proved that the specially developed TORQ-GARD oil satisfies the demands of high performance of the John Deere engines,

3. The exchange interval of the engine oil TORQ-GARD after $250 \mathrm{Eh}$ is appropriate.

\section{Acknowledgements}

This research was supported by the University of Pardubice - Student Grant Competition (No. SGS_2019_010).

\section{References}

[1] Majdan R., Tkáč Z., Abrahám R., Kollárová K., Vitázek I., Halenár, M. Filtration Systems Design for Universal Oils in Agricultural Tractors. Tribology in Industry, vol. 39(4), 2017, pp. 547-558.

[2] Tkáč Z., Čorňák Š., Cviklovič V., Kosiba J., Glos J., Jablonický J., Bernát R. Research of biodegradable fluid impacts on operation of tractor hydraulic system. Acta technologica agriculturae, vol. 20(2), 2017, pp. 42-45.

[3] Tulík J. et al. Evaluation of new biodegradable fluid on the basis of accelerated durability test, FTIR and ICP spectroscopy. Research in Agricultural Engineering, vol. 63(1), 2017, pp. 1-9.

[4] Kučera M., Aleš Z., Mareček J., Máchal P. Effect of Contamination on the Lifetime of Hydraulic Oils and Systems. Acta Universitatis Agriculturae et Silviculturae Mendelianae Brunensis, vol. 65(4), 2017, pp. 1205-1212.

[5] Dostál P., Rozlivka J., Kumbár V. Operational Degradation of Engine Oil in Agricultural Technology. Acta Technologica Agriculturae, vol. 22(1), 2019, pp. 17-21. 
[6] Gołębiowski W., Wolak A., Zając G. Definition of oil change intervals based on the analysis of selected physicochemical properties of used engine oils. Combustion Engines, vol. 172(1), 2018, pp. 44-50.

[7] Zając G., Wolak A., Szyszlak-Bargłowicz J. Wpływ dolewek oleju silnikowego na zawartość wybranych pierwiastków śladowych. Przemysł Chemiczny, vol. 97(5), 2018, pp. 788-791. (In Polish)

[8] Kosiba J., Čorňák Š., Glos J., Jablonický J., Vozárová V., Petrović A., Csilllag J. Monitoring oil degradation during operating test. Agronomy Research, vol. 14(5), 2016, pp.1626-1634.

[9] Macian V., Tormos B., Olmeda P., Montoro L. Analytical approach to wear rate determination for internal combustion engine condition monitoring based on oil analysis. Tribology International, vol. 36(10), 2003, pp. 771-776.

[10] Sejkorová M. Application of FTIR spectrometry using multivariate analysis for prediction fuel in engine oil. Acta Universitatis Agriculturae et Silviculturae Mendelianae Brunensis, vol. 65(3), 2017, pp. 933-938.

[11] Sejkorova M., Sarkan B., Caban J., Marczuk A. O zależności widm w podczerwieni zużytych olejów silnikowych od ich lepkości kinematycznej. Przemysl Chemiczny, vol. 97(1), 2018, pp. 49-54. (In Polish)

[12] Belogusev V., Kozlov K., Egorov A. et al. Method and instruments to measure dynamic viscosity of oil products in pipeline. Proceedings of the international scientific conference "Engineering for rural development 2018", May 23-25, 2018, Jelgava, Latvia, pp. 937-942.

[13] Kumbár V., Dostál P. Oils degradation in agricultural machinery. Acta Universitatis Agriculturae et Silviculturae Mendelianae Brunensis, vol. 61(5), 2013, pp. 1297-1303.

[14] Wu T. H., Mao J. H., Wang J. T., Wu J. Y., Xie Y. B. A new on-line visual ferrograph. Tribology transactions, vol. 52(5), 2009, pp. 623-631.

[15] Kučera M., Aleš Z. Morphology analysis of friction particles generated in tractor transmission oils. Acta Technologica Agriculturae, vol. 20(3), 2017, pp. 57-62.

[16] Kučera M., Aleš Z., Pexa M. Detection and characterization of wear particles of universal tractor oil using a particles size analyzer. Agronomy Research, vol. 14(4), 2016, pp. 1351-1360.

[17]Latip S. A., Kasolang S., Michael Z., Adnan, A. N. Oil analysis of used Perodua automatic transmission fluid (ATF-3) using spectrometric technique. Journal of Advanced Research in Fluid Mechanics and Thermal Sciences, vol. 28(1), 2016, pp. 17-25.

[18] Rahman N. A., Katon M. Wear Element Monitoring by Spectrometric Analysis in Automatic Transmission Bus. Journal of Advanced Research in Fluid Mechanics and Thermal Sciences, vol. 50(2), 2016, pp. 89-96.

[19] Golebiowski W., Zajac G., Wolak A. Zawartość metali w olejach silnikowych z ciągników rolniczych. Przemysl Chemiczny, vol. 97(5), 2018, pp. 696-699. (In Polish)

[20]Bekana D. et al. Monitoring of Agricultural Machines with Used Engine Oil Analysis. Acta Universitatis Agriculturae et Silviculturae Mendelianae Brunensis, vol. 63(1), 2015, pp. 15-22.

[21] Urzędowska W., Stępień Z.. Wybrane zagadnienia dotyczące zmian właściwości silnikowego oleju smarowego w eksploatacji. Nafta-Gaz, 12.LX, 2012, pp. 1102-1110. (In Polish)

[22] Sejkorová M., Glos J. Analysis of degradation of motor oils used in Zetor tractors. Acta Universitatis Agriculturae et Silviculturae Mendelianae Brunensis, vol. 65(1), 2017, pp. 179-187.

[23] Plaščak I., Jurić T., Emert R. Application of ferrography in condition based maintenance. Strojarstvo: časopis za teoriju i praksu u strojarstvu, vol. 52(2), 2010, pp. 233-240. 